\title{
Influence of locust bean waste ash on cation exchange and plasticity characteristics of cement modified lateritic soil
}

\author{
Muhammad, Muktar Namadi ${ }^{1, ~ *, ~ Y a m u s a, ~ B e l l o ~ Y a m u s a ~}{ }^{2}$ \\ ${ }^{1}$ Department of Chemistry, Nigerian Defence Academy, Kaduna \\ ${ }^{2}$ Department of Civil Engineering, Nuhu Bamalli Polytechnic, Zaria
}

Email address:

ammimuktar@yahoo.com(Muhammad, Muktar Namadi)

\section{To cite this article:}

Muhammad, Muktar Namadi; Yamusa, Bello Yamusa. Influence of Locust Bean Waste Ash on Cation Exchange and Plasticity Characteristics of Cement Modified Lateritic Soil. American Journal of Civil Engineering. Vol. 1, No. 2, 2013, pp. 58-63. doi: 10.11648/j.ajce.20130102.12

\begin{abstract}
A laboratory testing programme was carried out to investigate the influence of Locust Bean Waste Ash (LBWA) on cation exchange and plasticity characteristics of Ordinary Portland Cement (OPC) modified lateritic soil. Preliminary tests were carried out on the natural soil to determine its properties. Other tests were carried out on soil-cement mixtures with up to $4 \%$ OPC admixed with $8 \%$ locust bean waste ash content by dry weight. Improvement in the plasticity characteristics of the soil was reflected in the decrease of liquid limit, increase in plastic limit and decrease in plasticity index with increased cement and locust bean waste ash content. The results using analysis of variance showed statistical significance. These results showed that modification with cement and locust bean waste ash blend significantly improved the plasticity characteristics through cation exchange of the lateritic soil.
\end{abstract}

Keywords: Cation, Cement, Lateritic Soil, Locust Bean

\section{Introduction}

Laterite is a residual of rock decay that is reddish in colour and has a high content of oxides of iron and hydroxides of aluminum and low proportion of silica. The word laterite describes material with reasonably constant properties; it can signify a different material to people living in different parts of the world (Osinubi, 2008). They are formed under weathering systems productive of the process of laterization, the important characteristics of which is the decomposition of ferro-alumino silicate minerals and the permanent deposition of sesquioxides within the profile to form the horizon of material known to the engineer and builder as laterite (Gidigasu, 1976).

In Nigeria, laterite is used as a road making material and it forms the sub-grade of most tropical roads, it is used as sub base and base for low cost roads that carry low to medium traffic. Furthermore, in rural areas of Nigeria the soil is used as a building material for moulding of blocks and plastering.

Most Nigerian laterites are composed predominantly of kaolinite clay mineral with some quartz. In some cases, they contain swelling clay mineral type such as vermiculite, hydrated halloysite and montmorillonite (Ola, 1974). When laterite contains swelling clay mineral type, they are known as 'Problem Laterite' the reason being that they have the reputation of being problematic in road construction (Gidigasu, 1976).

Generally, if laterite does not meet the specification that they are meant for, modifying them or stabilizing them or the combination of the two improves their engineering properties. Cement and lime are the conventional materials that are generally used. The precise cement and lime requirements for modification and stabilization of different soils have to be determined by laboratory test of such soil properties using Atterberg limits tests. Cement stabilization is uneconomical for plastic limits greater than $20 \%$ and liquid limit greater than between 45 to 50 percent, (Maclean, 1953). The strength of soil plus cement is evaluated using either unconfined compression strength or direct shear box test (Maclean, 1953) and BS 1377(1990).

Modification is aimed at improving the workability of a soil. A great number of substances have been used for soil modification and much research is going on to find the most suitable modifier for each soil type 
(Osinubi and Alhassan, 2008; Osinubi et al 2009a, b).

The locally available material to be used in this study in combination with cement in laterite soil modification is locust bean waste ash (LBWA). The locust bean is the remains of fibrous waste after the extraction of the fruit from husk. It has three components namely:

- $\quad$ The husk

- The powder and

- The seed commonly used to produce local seasoning for food.

Out of these components, the waste product is the husk which when burnt in an open place will eventually result to LBWA.

Researchers like Mohammed, (1997) and Akolo, (2000) modified lateritic soilcrete building blocks with extract obtained from the husks of the ripe fruit of locust bean tree which is in the organic form. Also, Akinmade, (2008) used burnt locust bean waste ash (i.e., LBWA) to stabilize black cotton soil.

Portland cement and lime are the known conventional additives for modifying properties of soils. The use of waste by-product emanates from the need to economically reduce the quantity of Portland cement and lime required to modify and stabilize soils. Portland cement modification and stabilization involves addition of known quantity of cement by weight of dry soil to achieve the desired engineering properties.

Yoder and Witczak (1975) concluded that all laterite soil could be modified using 0.5 to $4 \%$ of cement and lime for base construction. Modification of clays changes water film. It also improves poorly graded base and sub-base. The methods of evaluation are Atterberg limits and particle size analysis.

In a certain situation, cement may be used to decrease soil plasticity; this is often termed as "Sweetening the soil" (Yoder and Witczak, 1975). Cement generally brings about a decrease in liquid limit and an increase in the plastic limit with a corresponding decrease in the plasticity index. The increase in plastic limit is accompanied by corresponding increase in optimum moisture content (Yoder and Witczak 1975).

The Nigeria General Specifications (1997) specifies the limit to be met as follows for base materials particles of the soil: $30 \%$ liquid limit, $12 \%$ plasticity index, $\mathrm{A}-2-6$ as AASHTO classification and $25 \%$ passing B.S. sieve No. 200. For sub base material, the liquid limit, plasticity index and AASHTO classification are the same as that specified for base material with the exception that the percentage passing the B.S. sieve No 200 is $35 \%$. Locust bean is readily available and cheap material that could be use to improve the engineering properties of the soil. This paper seeks to evaluate the potential role of Locust bean otherwise considered as waste - as a viable material for enhancing soil properties in construction purposes.

\section{Materials and Methods}

The soil sample used for this study was collected from a borrow pit near the new Ahmadu Bello University Teaching Hospital at Longitude $7^{\circ} 36^{\prime}$ E latitude $11^{\circ} 4^{\prime} \mathrm{N}$, in Shika Area of Zaria along Zaria - Funtua Road. It belongs to ferruginous tropical soils derived from acid igneous and metamorphic rocks.

The locust bean waste ash was obtained locally from burning of locust bean husks sourced from Maigiginya, Igabi Local Government Area, Kaduna State. Only ash that passed through BS No. 200 (75 $\mu \mathrm{m}$ aperture) sieve was used for the study.

Preliminary classification tests were carried out to determine the geotechnical properties of the natural soil sample. The soil sample was then treated with 1,2, 3 and $4 \%$ cement content by dry weight of the soil sample while locust bean waste ash was admixed at $0,2,4,6$ and $8 \%$ by dry weight of the soil sample. Tests were carried out in accordance with BS 1377 (1990) and BS 1924 (1990) for natural and modified soil respectively.

Statistical Analysis of the results obtained was achieved using two ways analysis of variance (ANOVA) from Microsoft excel software.

\section{Results and Discussions}

\subsection{Soil Identification}

The results of the preliminary tests carried out on the natural soil are summarized in Table 1. The soil is classified as A-7-6 (10) based on an AASHTO classification (AASHTO, 1986) and CL based on the Unified Soil Classification System (ASTM, 1992). The colour of the soil is yellowish brown.

\subsection{Oxide Composition of Locust Bean Waste Ash}

A comparison of the oxide composition of the LBWA used in the study obtained by x-ray fluorescence (XRF) analysis method with that of the ordinary Portland cement (Akinmade, 2008) is given in Table 2. The ASTM C61878(1978) specify the combined weight of silica, alumina and ferrous oxides as $70 \%$ for classes of $\mathrm{N}$ pozzolanas, which the locust bean waste ash has satisfied.

Table 1: Properties of the natural soil

\begin{tabular}{ll}
\hline Property & Quantity \\
\hline & \\
Percentage passing No. 200 B.S. sieve & 63.0 \\
Natural Moisture Content & 8.13 \\
Liquid Limit (\%) & 41.0 \\
Plastic Limit (\%) & 18.5 \\
Plasticity index (\%) & 22.5 \\
Linear Shrinkage (\%) & 8.9 \\
Group index & 10 \\
AASHTO Classification & A-7-6 \\
Specific Gravity & 2.67 \\
Colour & Yellowish brown \\
\end{tabular}


Table 2: Oxide composition of ordinary Portland cement and locust bean waste ash

\begin{tabular}{lll}
\hline Oxide Composition & $\begin{array}{l}\text { \% Concentration } \\
\text { "Ordinary Portland } \\
\text { Cement }\end{array}$ & $\begin{array}{l}\text { **t Locust bean } \\
\text { waste ash }\end{array}$ \\
\hline $\mathrm{CaO}$ & 63 & 1.08 \\
$\mathrm{SiO}{ }_{2}$ & 20 & 55.38 \\
$\mathrm{Al}_{2} \mathrm{O}_{3}$ & 6 & 14.93 \\
$\mathrm{Fe}_{2} \mathrm{O}_{3}$ & 3 & 0.28 \\
$\mathrm{MgO}$ & - & 0.09 \\
$\mathrm{SO}_{3}$ & 2 & - \\
$\mathrm{Na}_{2} \mathrm{O}$ & 1 & 0.18 \\
$\mathrm{~K}_{2} \mathrm{O}$ & - & 2.0 \\
$\mathrm{P}_{2} \mathrm{O}_{5}$ & - & 0.23 \\
$\mathrm{LosS}$ on Ignition & 2 & 10.63 \\
\hline
\end{tabular}

* Czernin 1962, ** Akinmade 2008

\subsection{Cation Exchange Capacity}

Some clay undergoes isomorphous substitution, that is, substitution of cation of one kind by another while retaining the same crystal structure. This substitution, along with the dissociation of hydroxyl ions, results in a residual negative charge on the surface of the clay's mineral particles. Positively charged ions (i.e cations), are therefore adsorbed on its surface. These ions are not strongly held and can be replaced by others present in water. This phenomenon is described as cation exchange. The quantity of exchangeable cation in a soil is termed exchange capacity (Gidigasu, 1976).

These cations enter the absorbed layers and constitute what is termed as an adsorption complex. The process of replacing cations of one kind by those of another in an adsorption complex is known as exchange. By Base Exchange is meant the capacity of colloidal particles to change the cations absorbed on their surface. Thus hydrogen clay (colloid with absorbed $\mathrm{H}$ cations) can be changed to sodium clay (colloid with absorbed Na cations) by a constant percolation of water containing dissolved $\mathrm{Na}$ salts. Such changes can be used to decrease the permeability of a soil (Muazu, 2006).

When water is added to soil particle, the negative charge on the surface attracts the positive (hydrogen) end of water molecules to form an adsorbed film of water. This adsorbed film of water is thicker than the diameter of the particles (in the case of fine- grained soil) which allows the movement of grains across one another. This property improves the plasticity of the soil as the soil can deform plastically without cracking when mixed with varying amount of water. Similarly, this is in agreement with the findings of Ola (1983), Osula (1991) and Osinubi (1995) that addition of lime caused the flocculation and agglomeration of the clay particles through cation exchange at the surface of the clay particles and the highly plastic nature of lime which caused the plastic limits to increase drastically.

The cation exchange capacity (CEC) of the soil increased appreciably with increased locust bean waste ash (LBWA) content while slight increase occurred with increase in cement content. This indicates that the CEC of the soil can be improved by mixing it with cement - LBWA blend or LBWA alone because of its high quantity of exchangeable cations. The variations of CEC of cement modified soil and LBWA modified soil with LBWA and cement contents are shown in Figs. 1 and 2 respectively. The variation of liquid limit between locust bean waste ash (LBWA) and cement using the Two-way Analysis of Variance (ANOVA) gives $\mathrm{F}_{\mathrm{STAT}}=10.5>\mathrm{F}_{\mathrm{CRIT}}=3.0$, and $\mathrm{F}_{\mathrm{STAT}}=3.1>\mathrm{F}_{\mathrm{CRIT}}=3.0$, respectively. These results confirmed a significant effect of cement and LBWA increments.

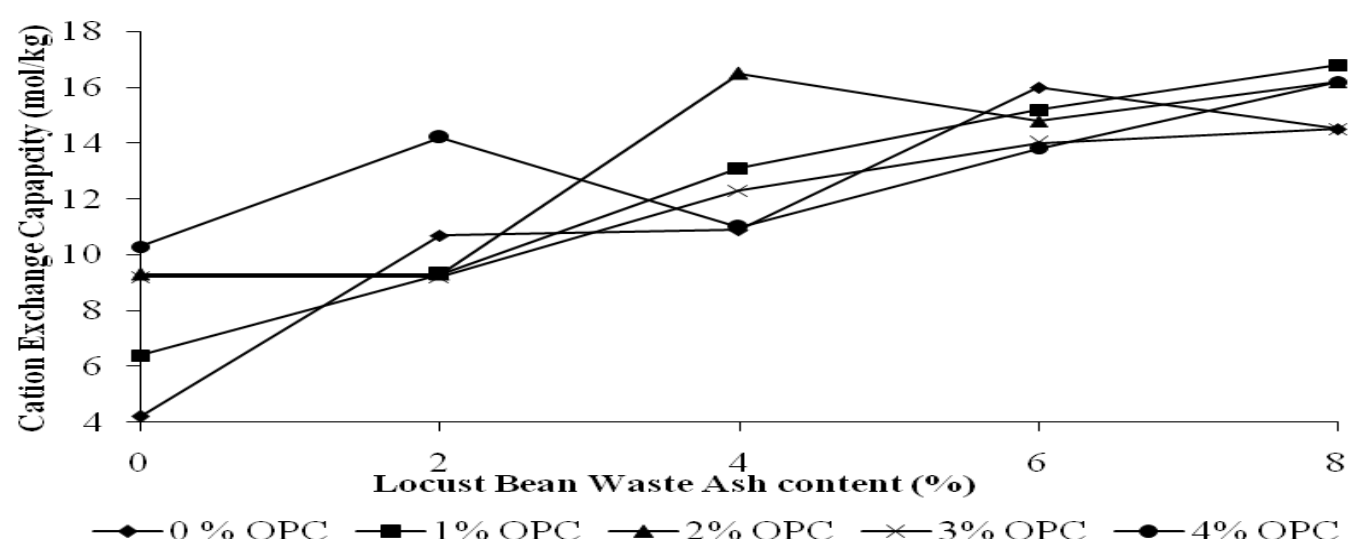

Fig. 1: Variation of cation exchange capacity of cement modified soil with locust bean waste ash content 


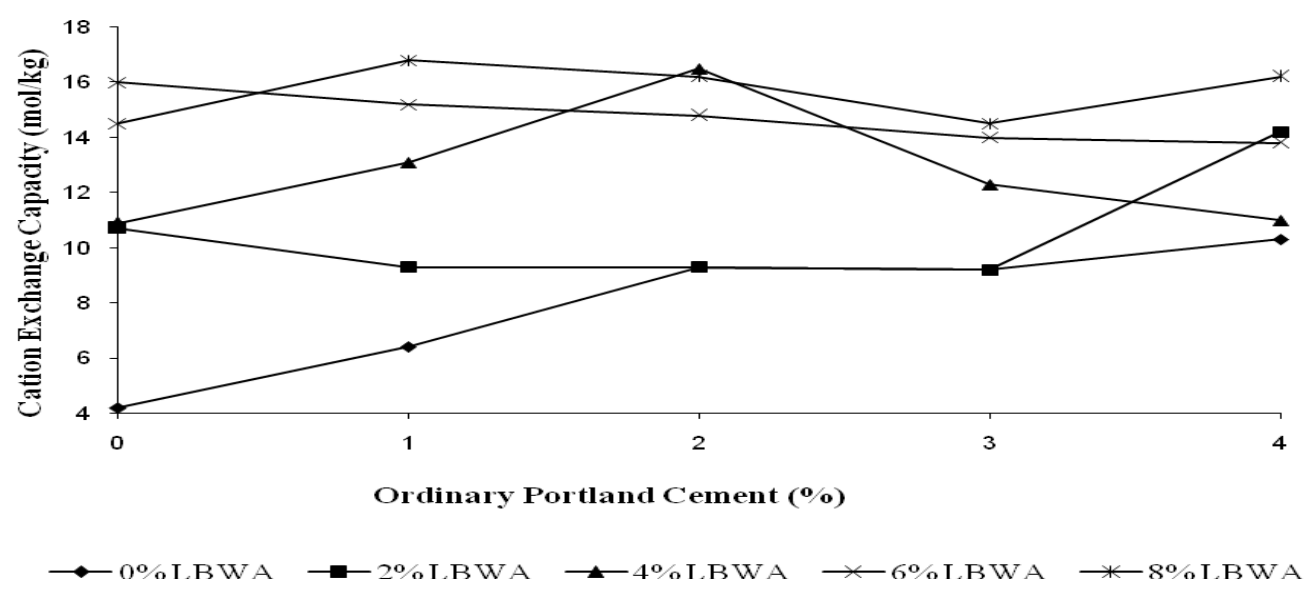

Fig. 2: Variation of cation exchange capacity of locust bean waste ash modified soil with cement content

\subsection{Atterberg Limits}

\subsubsection{Liquid Limit}

The variation of liquid limit with soil - ordinary Portland cement (OPC) mixtures and locust bean waste ash (LBWA) blend is shown in Fig. 3. Liquid limit (LL) reduced with higher OPC/LBWA content. The LL value for the natural soil ranged from $41.4 \%$ to $38.4 \%$ when treated with up to $8 \%$ LBWA content. On treatment with 1, 2, 3 and 4\% OPC and up to $8 \%$ LBWA content, LL reduced from 38.7 to $37.4 \%, 39.3$ to $38.4 \%, 38.8$ to $37.8 \%$ and 40.4 to $37.9 \%$, respectively. The reduction in LL with higher OPC/LBWA blend content could be attributed to the reduction of free silt and clay in the soil due to the cation exchange and the formation of coarse grained material of lower moisture holding capacity and increased volume stability (Obeahon, 1993; Osinubi and Alhassan 2008a). The variation in liquid limit between locust bean waste ash and cement using the Two-way Analysis of Variance (ANOVA) gives $\mathrm{F}_{\mathrm{STAT}}=$ $20.2>\mathrm{F}_{\mathrm{CRIT}}=3.0$, and $\mathrm{F}_{\mathrm{STAT}}=10.6>\mathrm{F}_{\mathrm{CRIT}}=3.0$, respectively; hence they are statistically significant.

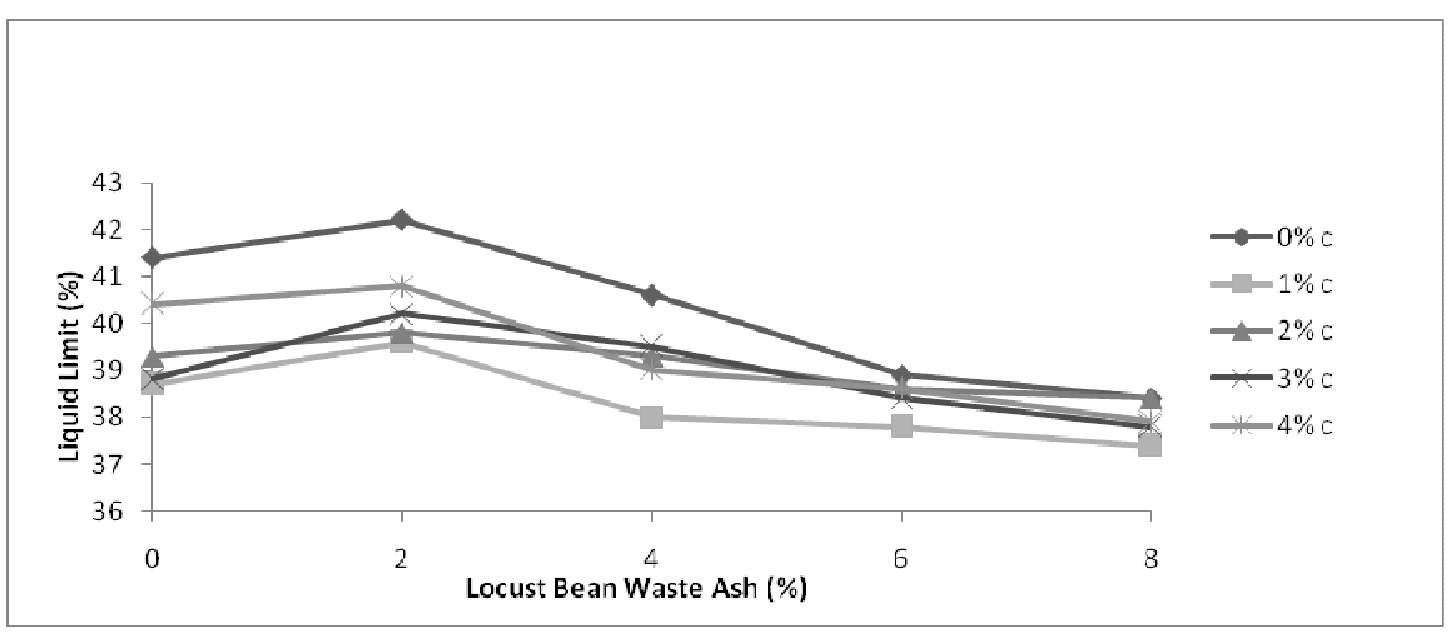

Fig. 3: Variation of liquid limit of cement modified soil with locust bean waste ash content

\subsubsection{Plastic Limit}

The variation of plastic limit with soil - ordinary Portland cement (OPC) mixtures and locust bean waste ash (LBWA) blend is shown in Fig. 4. Plastic limit increased with higher cement and LBWA contents. The plastic limit value for the natural soil ranged from $18.5 \%$ to $29.7 \%$ treated with up to $8 \%$ LBWA content. On treatment with 1 , 2,3 and $4 \%$ OPC and up to $8 \%$ LBWA content, PL increased from 26.4 to $30.6 \%, 28.9$ to $34.2 \%, 30$ to $30.1 \%$ and 31.2 to $31.6 \%$, respectively. The trend is in agreement with the findings of Ola (1978), Osula (1991) and Osinubi (1995) that addition of lime caused the flocculation and agglomeration of the clay particles through cation exchange at the surface of the clay particles and the highly plastic nature of lime which caused the plastic limits to increase. The variation in plastic limit between locust bean waste ash and cement using the Two-way Analysis of Variance (ANOVA) gives $\mathrm{F}_{\mathrm{STAT}}=18>\mathrm{F}_{\mathrm{CRIT}}=3.0$, and $\mathrm{F}=$ $25.7>\mathrm{F}_{\mathrm{CRIT}}=3.0$, respectively; hence they are statistically significant. 


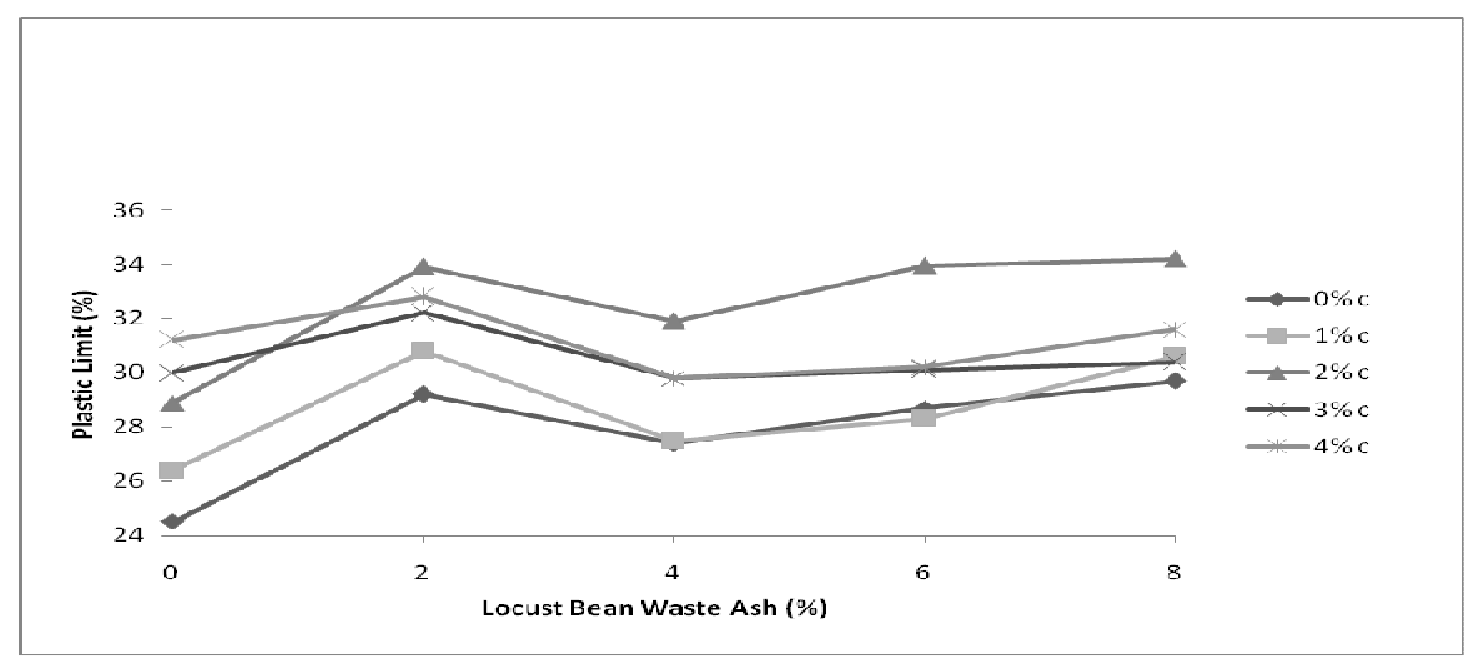

Fig. 4: Variation of plastic limit of cement modified soil with locust bean waste ash content

\subsection{Plasticity Index}

The variation of plasticity index (PI) with soil - ordinary Portland cement (OPC) mixtures and locust bean waste ash (LBWA) blend is shown in Fig. 5. Generally, plasticity index reduced with higher cement and LBWA contents. The plasticity index value for the natural soil ranged from 16.9 to $8.7 \%$ when treated with up to $8 \%$ LBWA content. On treatment with 1, 2, 3 and $4 \%$ OPC and up to $8 \%$ LBWA content, PI reduced from 12.29 to $6.8 \%, 10.4$ to $4.2 \%, 8.8$ to $7.4 \%$ and 9.2 to $6.3 \%$, respectively. This trend may be attributed to the replacement of the finer soil particles by the LBWA with consequent reduction in the clay content and plasticity index. The variation in plasticity index between locust bean waste ash and cement using the Twoway Analysis of Variance (ANOVA) gives $\mathrm{F}=11.5>\mathrm{F}_{\mathrm{CRIT}}$ $=3.0$, and $\mathrm{F}_{\mathrm{STAT}}=16.3>\mathrm{F}_{\mathrm{CRIT}}=3.0$, respectively; hence they are statistically significant.

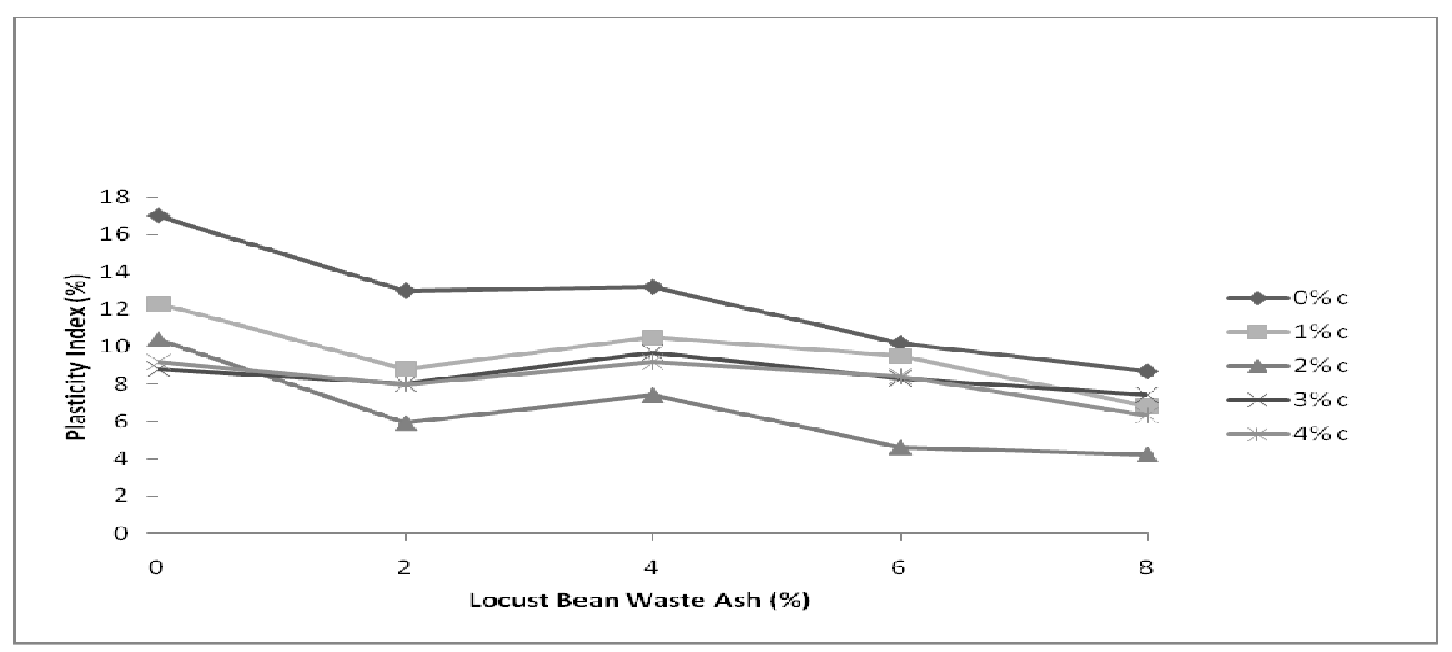

Fig. 5: Variation of plasticity index of cement modified soil with locust bean waste ash content

\section{Conclusion}

The lateritic soil used in this study is classified to be an A-7-6(10) and CL according to Unified Soil Classification System. It is a soil of medium plasticity with about $63 \%$ of the soil particles passing through the BS. No 200 sieve.

The Liquid limit of the lateritic soil sample decreased while the Plastic limit increased with increased cement/LBWA treatment. An indication of improvement of geotechnical properties of the lateritic soil is evident from the decrease in the plasticity index from $12.29 \%$ for the natural soil to $6.82 \%$ when treated with $1 \%$ cement $/ 8 \%$ LBWA content. Based on Nigerian General Specifications (1997 clause 6201) requirements, the modified soil met the $12 \%$ maximum plasticity index value for use as subbase or base material, however the liquid limit requirement of a maximum of $35 \%$ was not met for use as subbase and base course material, but there was an improvement recorded from $38.7 \%$ for the natural soil to $37.4 \%$ when treated with $1 \%$ cement $/ 8 \%$ LBWA content. 


\section{References}

[1] AASHTO (1986). Standard Specification for Transportation, Material and Methods of Sampling and Testing. 14th Edition. American Association of State Highway and Transportation Officials, Washington D.C.

[2] Akinmade, (2008). Stabilization of Black Cotton Soil Using Locust Bean Waste Ash. Unpublished M.Sc. Thesis Civil Engineering Department, Ahmadu Bello University Zaria.

[3] Akolo, F.P.(2000) "Rheological Properties of Makuba Stailised Soilcrete Blocks Unpublished M.Sc. Thesis. Submitted to the Civil Engineering Department, Ahmadu Bello University, Zaria.

[4] ASTM (1992). Annual Book of Standards. Vol. 04.08, American Society for Testing and Materials. Philadelphia.

[5] ASTM C618-78 (1978). Specification for Fly Ash and Raw or Calcinated Natural Pozzolanas for Use as a Mineral Admixture in Portland Cement Concrete. American Society for Testing and Materials, Philadelphia.

[6] BS 1377 (1990). "Method of testing soil for engineering purpose". British Standard Institute, BSI, London, England.

[7] BS 1924 (1990) "Method of test for stabilized soils". British Standard Institute, BSI, London, England.

[8] Czernin, W. (1962). "Cement Chemistry and Physics for Civil Engineers", Crosby Lockwood, London.

[9] Gidigasu M. D., (1976). Laterite Soil Engineering Pedogenesis and Engineering Principles. Elsevier Scientific Publication Company, Amsterdan, pp.444-482.

[10] Maclean D.T. (1953). "Investigation of some problems in soil stabilization". Proceeding of third international conference on soil mechanics and foundation Engineering England pp.263-267.

[11] Mohammed, M.S. (1997) "Improved Solid Sancrete blocks for Low-cost Buildings". Unpublished M.Sc Thesis, Civil Engineering Department, Ahmadu Bello University, Zaria.

[12] Muazu M. Abdullahi (2006) "Effect of Bagasse Ash on Cement Modified Laterite". Unpublished M.Sc Thesis, Civil Engineering Department Ahmadu Bello University Zaria.

[13] Nigerian General Specifications (1997). Roads and Bridgeworks. Federal Government of Nigeria, Lagos, Nigeria.

[14] Obeahon, S. O. (1993). The Effect of Elapsed Time After Mixing on the Properties of Modified Laterite Unpublished M.Sc. Thesis Civil Engineering Department, Ahmadu Bello University, Zaria.

[15] Ola, S. A. (1974) "Need for estimated cement requirement for stabilizing lateritic soil.” J. Transport Div., ASCE, Vol. 17, No 8, pp. 379-388.

[16] Ola, S. A. (1978) "Geotechnical properties and behavior of some stabilized Nigerian Laterite Soil”. Q.T.J Eng Goe London vol.11l pp.145-160

[17] Ola, S.A. (1983)."The geotechnical properties of black cotton soils of North Eastern Nigeria" In: S.A. Ola (Editor. Tropical soils of Nigeria in Engineering Practice, A.A.Balkema, The Netherlands, Rotterdam, 155-171).

[18] Osinubi, K.J. (1995). "Lime modification of black cotton soil” Spectrum Journal Kaduna, Vol.2, pp.112-122.

[19] Osinubi, K. J. (2008) "Laterite soils and other proplem soils of Africa”. Unpublished MSc Lecture notes A.B.U., Zaria.

[20] Osinubi K. J. and Alhassan M., (2008a). "Use of lime and bagasse ash in modification of laterite." Nigerian Journal of Engineering Vol. 14, No 1, pp.70-80.

[21] Osinubi, K. J, Akinmade, O. B, and Eberemu, O. A. (2009a). "Stabilization potential of locust bean waste ash on Black Cotton Soil". Journal of engineering research. vol. 14, No. 2, pp. 1-13.

[22] Osinubi, K. J, Eberemu, O. A, and Amadi A. A. (2009b). "Compacted lateritic soil treated with Blast Furnance Slag as hydraulic barriers in waste containment". International journal, risk assessment and management. Vol. 13, No. 2, pp. 171-188.

[23] Osula, D. O. A. (1991). "Lime modification of problem laterite”. Eng'g. Geol. 30, pp 141-149

[24] Yoder E.J and witczak M.W (1975) "Principles of Pavement Design" second edition. 